\title{
Bioturbation by the razor clam Sinonovacula constricta affects benthic nutrient fluxes in aquaculture wastewater treatment ecosystems
}

\author{
Li Zhao', Yuqi Zheng ${ }^{1}$, Regan Nicholaus ${ }^{1}$, Betina Lukwambe ${ }^{1}$, Jinyong Zhu ${ }^{1,2}$, \\ Wen Yang ${ }^{1,2}$, Zhongming Zheng ${ }^{1,2, *}$ \\ ${ }^{1}$ School of Marine Sciences, Ningbo University, Ningbo 315211, PR China \\ ${ }^{2}$ Collaborative Innovation Center for Zhejiang Marine High-efficiency and Healthy Aquaculture, Ningbo 315211, PR China
}

\begin{abstract}
The rapid development of the aquaculture industry has led to the growth of environmental problems. Bioremediation is an effective method for treating aquaculture effluents. A $30 \mathrm{~d}$ laboratory experiment was conducted to investigate the effects of Sinonovacula constricta bioturbation on sediment and nutrient fluxes across the sediment-water interface in aquaculture wastewater treatment ecosystems. The experiment was designed with 3 treatment groups and 1 control with 3 replicates each. The rates of sediment oxygen consumption (SOC) and the physical and chemical properties of the sediment and nutrient fluxes $\left(\mathrm{NH}_{4}{ }^{+}, \mathrm{NO}_{3}{ }^{-}+\mathrm{NO}_{2}{ }^{-}\right.$and $\left.\mathrm{PO}_{4}{ }^{3-}\right)$ were determined. After the experiment, the levels of total organic nitrogen, total organic carbon, and total phosphorus in the surficial sediment of the treatment groups had declined significantly, and the alkaline phosphatase content and microbial activity had increased significantly $(p<0.05)$. SOC rate in all treatment groups was significantly higher than that in the control group before Day 24 and increased with clam density (no. of clams per unit area) $(\mathrm{p}<0.05)$; in most treatment groups, nutrients $\left(\mathrm{NH}_{4}{ }^{+}, \mathrm{NO}_{3}{ }^{-}+\mathrm{NO}_{2}{ }^{-}\right.$and $\left.\mathrm{PO}_{4}{ }^{3-}\right)$ were released from the sediment into the overlying water, and the rate of release increased with clam density and time. The results obtained in this study revealed that bioturbation by $S$. constricta reduced organic matter accumulation and accelerated the mineralization of organic matter in the sediments, which may promote nutrient recycling in aquaculture wastewater treatment ecosystems and eventually bioremediate aquaculture effluents.
\end{abstract}

KEY WORDS: S. constricta $\cdot$ Effluent $\cdot$ Bioremediation $\cdot$ Nitrate/nitrite $\cdot$ Sediment-water interface

\section{INTRODUCTION}

The rapid development of the aquaculture industry has been accompanied by an increase in environmental impacts. Intensive aquaculture production generates increasingly substantial amounts of polluted effluent (Ziemann et al. 1992, Hopkins et al. 1993), resulting in eutrophication and environmental deterioration of the receiving waters. As a conse-

*Corresponding author: zhengzhongming@nbu.edu.cn quence, many efforts have been made to find an effective treatment to minimize the negative effects of aquaculture activities (Marinho-Soriano et al. 2009, Jones et al. 2001). There are currently 3 main treatment methods for aquaculture wastewater: physical, chemical and bioremediation (Gupta \& Ali 2012). Among them, bioremediation is thought to be the most effective and environmentally friendly method due to its advantages of low cost, simple operation

(C) The authors 2019. Open Access under Creative Commons by Attribution Licence. Use, distribution and reproduction are unrestricted. Authors and original publication must be credited. 
and high security (MacDonald \& Rittman 1993). At present, one of the popular effluent treatments in China is an integrated method in which bioremediation is crucial (Bu et al. 2003). The treatment process includes natural sedimentation, aeration, shellfish filtering and macroalgae adsorption (Jones et al. 2001, Qin et al. 2017, Lukwambe et al. 2018). The organic matter of aquaculture effluent can be transformed into inorganic nutrients that can be utilized as a rich source of nutrients for phytoplankton under the action of aeration (Granéli et al. 1999). Phytoplankton is recognized as a rapidly growing plant that can quickly absorb nutrients. In the shellfish filtering area, bioturbation by benthic shellfish may enhance the mineralization of organic matter; the release of nutrients from the sediment significantly improves nutrient recycling in the effluent treatment ecosystem because the feeding, burrowing and other activities of the shellfish alters the physical, chemical and ecological properties of the sediment (Thayer 1979, Meysman et al. 2006, Creed et al. 2010, Nicholaus \& Zheng 2014, Zheng et al. 2017). Shellfish, such as razor clams Sinonovacula constricta and Tagelus plebeius (Klerks et al. 2018), may then feed on the phytoplankton that is promoted by the released nutrients and suspended organic particulates in the water. Thus, organically enriched sediment may be bioremediated by benthic shellfish, and the released nutrients may further promote the growth of phytoplankton, which could be reabsorbed by the shellfish (Meysman et al. 2006, Tian et al. 2016, Zheng et al. 2017). Therefore, razor clams play a key role in this ecosystem, and it is important to understand the extent and mechanisms of their effects.

The razor clam $S$. constricta has become one of the most commercially important mariculture species in China in recent years, with annual production of razor clams reaching about $78000 \mathrm{t}$ (Du 2016). The clams live in muddy or sandy tidal flats along the coastal intertidal zone with a buried and burrowed habitat (Wang \& Wang 2008). The polyculture of $S$. constricta with other animals is now widely implemented in the coastal areas of China and is also widely used in aquaculture wastewater treatment systems (Tian et al. 2001, Bu et al. 2003, Zheng et al. 2017, Lukwambe et al. 2018). Studies on the impact of bioturbation on nutrient flux at the sedimentwater interface have been well reported thus far; e.g. Nicholaus \& Zheng (2014) found that Cyclina sinensis could increase the fluxes of inorganic nutrients $\left(\mathrm{NH}_{4}{ }^{+}, \mathrm{NO}_{3}{ }^{-}+\mathrm{NO}_{2}{ }^{-}, \mathrm{PO}_{4}{ }^{3-}\right)$ and sediment oxygen consumption (SOC) across the sediment-water interface. Chironomus plumosus can promote the forma- tion of Fe/Al-P and Ca-P in sediment (Cai et al. 2017). Wrede et al. (2017) found that Echinocardium cordatum enhanced the fluxes of ammonium and nitrite at the sediment-water interface. There are also reports of shellfish such as Anodonta woodiana, zebra mussels and Ruditapes philippinarum being used to remediate the eutrophication in shallow lakes (Wu et al. 2018, Bagdanavičiūtè et al. 2018, Breda et al. 2018). However, there are few studies on the role of bioturbators in the ecological treatment systems for aquaculture wastewater.

The primary aims of this study were to determine the effects of bioturbation by $S$. constricta on sediment physicochemical characteristics and benthic nutrient fluxes in aquaculture wastewater treatment ecosystems. The approach included establishing a mesocosm with different $S$. constricta stocking densities in indoor areas and measuring sediment biogeochemical characteristics, such as organic N, C and P contents, alkaline phosphatase content and microbial activities. Oxygen and nutrient fluxes were investigated across the sediment-water interface under dark incubations. The results of this study will increase the knowledge of the management of aquaculture wastewater treatment and improve understanding of how clams affect nutrient cycling in wastewater treatment systems.

\section{MATERIALS AND METHODS}

\subsection{Experimental materials}

The sediment and aquaculture wastewater for this study were collected from Chun Lin Aquaculture Farm, an intensive shrimp farm (raising Penaeus vannamei Boone) in Ningbo, Zhejiang Province, China. The $\mathrm{NH}_{4}{ }^{+}, \mathrm{NO}_{3}{ }^{-}+\mathrm{NO}_{2}{ }^{-}$and $\mathrm{PO}_{4}{ }^{3-}$ contents of the wastewater were $1.05,186.8$ and $0.58 \mathrm{mg} \mathrm{l}^{-1}$, respectively. The sediment comprised $71.2 \%$ silt and clay, 25\% sand and 3.8\% gravel, with an average particle size of $10.77 \mu \mathrm{m}$. The organic matter content of the sediment was $7.37 \pm 0.54 \%$, which was measured as loss upon ignition $\left(500^{\circ} \mathrm{C}\right)$. The sediments were sieved with $1 \mathrm{~mm}$ mesh prior to analysis to remove all heavy gravel, impurities and macrobiotics. Razor clam Sinonovacula constricta individuals (average wet weight: $5.092 \mathrm{~g}$ ) with integrated shells and high vitality were selected from the mudflat near the farm and acclimated for $10 \mathrm{~d}$ before being used in the experiment. During acclimation, the clams were fed every day with 2 laboratory-cultured microalgae: Nannochloropsis and Chlorella. 


\subsection{Mesocosm}

In the Aquatic-Ecological Laboratory of Ningbo University, a mesocosm was established using a $0.55 \mathrm{~m}^{3}$ plastic bucket with ca. $200 \mathrm{l}$ of the shrimp farm wastewater. Sieved sediments were added to 12 transparent cylindrical polypropylene (PP) chambers $(14.2 \mathrm{~cm}$ diameter; $18.6 \mathrm{~cm}$ height) to form an $8 \mathrm{~cm}$ thick sediment layer, and each chamber was equipped with 2 sampling ports, as described in Dollar et al. (1991) and Nicholaus \& Zheng (2014). The experiment was designed with 3 treatment groups and 1 control with 3 replicates each: (1) low density: 1 clam chamber $^{-1}$ (equivalent to 63.1 ind. $\mathrm{m}^{-2}$ ); (2) medium density: 2 clams chamber ${ }^{-1}$ (126.3 ind. $\left.\mathrm{m}^{-2}\right)$; (3) high density: 4 clams chamber ${ }^{-1}$ (252.6 ind. $\mathrm{m}^{-2}$ ); and (4) control: chambers with sediment and without clams. The treatment densities were set according to productive stocking density (the medium density treatment is the average stocking density on production scale). All chambers (without the lids) were placed into the mesocosm. Approximately $25 \%$ of the total volume of wastewater in the mesocosm was replaced with fresh wastewater every day. Aeration was provided to the mesocosm every $24 \mathrm{~h}$. The experiment lasted for $30 \mathrm{~d}$.

Water quality parameters, including water temperature (WT), salinity (S), pH and dissolved oxygen (DO), were measured daily using a YSI-550A oxygen meter before fresh wastewater was added to the mesocosm.

\subsection{Sampling and nutrient flux measurements}

The rates of nutrient fluxes and SOC were determined every $6 \mathrm{~d}$ through dark incubation in the laboratory, as previously described by Nicholaus \& Zheng (2014). Prior to dark incubations at each incubation time, all the PP-chambers were sealed with lids and carefully transferred from the mesocosm to the incubation water bath, and magnetic stirrers were used to keep the overlying water molecules evenly distributed (Fig. 1). The incubations lasted for $3 \mathrm{~h}$ in the water baths in darkness at in situ temperatures (Nicholaus \& Zheng 2014). Three chambers with clams and without sediment were also incubated as controls of incubation to correct the nutrient and DO contents. The DO of the overlying water was measured using a YSI-550A oxygen meter at the beginning and end of the $3 \mathrm{~h}$ incubation period. For nutrient flux $\left(\mathrm{NH}_{4}{ }^{+}, \mathrm{PO}_{4}{ }^{3-}, \mathrm{NO}_{3}{ }^{-}+\mathrm{NO}_{2}{ }^{-}\right)$measurements, $45 \mathrm{ml}$ of water samples were collected from a distance of $1 \mathrm{~cm}$

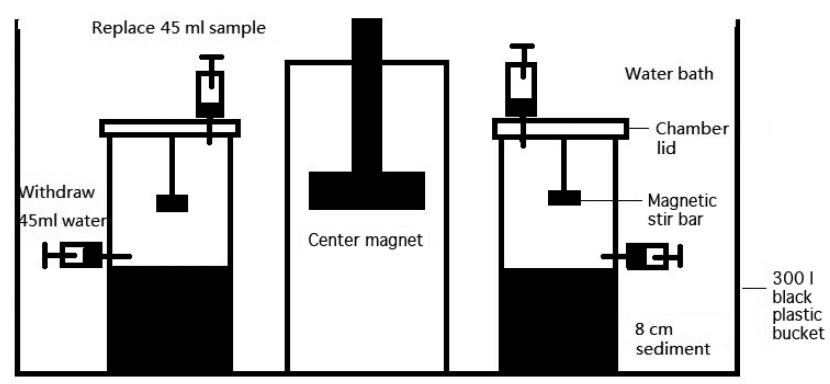

Fig. 1. Dark incubation device specifically designed for the present study

above the sediment using a syringe and needle at $1 \mathrm{~h}$ intervals $(0,1,2$ and $3 \mathrm{~h})$. The volume of water that was withdrawn was replaced with $45 \mathrm{ml}$ of fresh wastewater, to correct the concentration of nutrients in the overlying water of every chamber, which was measured simultaneously (Michaud et al. 2006). The extracted samples were immediately filtered through a $0.45 \mu \mathrm{m}$ GF/F Whatman glass fibre filter and frozen at $-20^{\circ} \mathrm{C}$ in $\mathrm{HCl}$-washed $\mathrm{PP}$ cryovial tubes for later analyses of $\mathrm{NH}_{4}{ }^{+}, \mathrm{PO}_{4}{ }^{3-}$ and $\mathrm{NO}_{3}{ }^{-}+\mathrm{NO}_{2}{ }^{-}$. After incubation, all chambers were placed back into the mesocosm, and the experiment continued. In the analysis, the indophenol blue method was used to determine ammonia, nitrate was measured with the cadmiumcopper reduction method and the phosphate concentration was determined using the ammonium molybdate method. All nutrients were measured with a WESTCO SmartChem discrete analyser.

\subsection{Sediment characteristics}

Initial and final sediment samples were taken from chambers with sterile Plexiglas tubes. Each final sediment sample ( $8 \mathrm{~cm}$ in depth) was divided into 3 layers $(0-2,2-5$ and $5-8 \mathrm{~cm})$ and frozen for later analyses of total organic nitrogen (TON), total phosphorus (TP), total organic carbon (TOC), alkaline phosphatase (APA) and microbial activity (MBA). The TON and TOC contents were determined using a vario EL Cube element analyser. TON and TOC were acidified by the gas phase method before determination. The sediments were placed in a dryer with concentrated hydrochloric acid overnight and then placed in a conventional laboratory oven at $60^{\circ} \mathrm{C}$ to remove the excess hydrochloric acid. TP was measured with the European Commission's SMT Programme-approved method (Murphy \& Riley 1962).

The sediment APA was analysed by means of $p$ nitrophenyl phosphate disodium (p-NPP) (Sayler et al. 1979): APA was determined spectrophotometri- 
cally as the release of p-nitrophenol from the model substrate $\mathrm{p}$-NPP. The reaction mixture for sediments contained $1 \mathrm{~g}$ sediment, $2.6 \mathrm{ml} 0.05 \mathrm{M}$ Tris-buffer $\mathrm{pH}$ 8.4, $0.03 \mathrm{ml} 0.1 \mathrm{M} \mathrm{MgCl}_{2}$ and $0.1 \mathrm{ml} 10 \mathrm{mM} \mathrm{p}$-NPP. Samples were incubated in a water bath at $37^{\circ} \mathrm{C}$ for $1 \mathrm{~h}$. After that, the reaction was immediately terminated by the addition of $0.3 \mathrm{ml} 1 \mathrm{M} \mathrm{NaOH}$. Finally, the samples were centrifuged, the clear liquid was collected and the samples were analysed spectrophotometrically at $418 \mathrm{~nm}$. The results of specific APA are reported in mg p-nitrophenol $\left(\mu g g^{-1} h^{-1}\right)$. All samples were executed in triplicate.

Sediment MBA was analysed by means of fluorescein diacetate (FDA) (Battin 1997): $2 \mathrm{~g}$ wet sediment sample was placed into the $50 \mathrm{ml}$ reaction tube; $15 \mathrm{ml}$ of $60 \mathrm{mM}$ phosphate buffer reagent $(\mathrm{pH}=7.6)$, and $0.2 \mathrm{ml}$ FDA reagent were added, at which point the reaction started. The sample was mixed uniformly at $30^{\circ} \mathrm{C}$, and then shaken (100 RPM) for $20 \mathrm{~min}$. No FDA substrate was added to the blank. Then, $15 \mathrm{ml}$ chloroform/methanol (volume ratio 2:1) was added to the solution and it was immediately shaken uniformly to stop the reaction. The tubes were centrifuged at $\sim 1500 \times g$ for $3 \mathrm{~min}$; the clear liquid was collected and put under $490 \mathrm{~nm}$ to measure absorbance. The units of the measured results were converted into dry weight of sediment.

\subsection{Data analyses}

Fluxes of dissolved inorganic nutrients $\left(\mathrm{NH}_{4}{ }^{+}, \mathrm{NO}_{3}{ }^{-}\right.$ $+\mathrm{NO}_{2}{ }^{-}$and $\mathrm{PO}_{4}{ }^{3-}$ ) were calculated from the slope of a linear regression of concentration against time (Michaud et al. 2006). The SOC rate was calculated according to the equation in Dollar et al. (1991):

$$
F=\frac{\Delta C \cdot V}{A \cdot t}
$$

where $F$ is the SOC flux $\left(\mathrm{mg} \mathrm{m}^{-2} \mathrm{~d}^{-1}\right), \Delta C$ is the change in the concentration of oxygen $\left(\mathrm{mg} \mathrm{l}^{-1}\right)$ before and after incubation, $V$ is the volume of overlying water $\left(\mathrm{m}^{3}\right), A$ is the cross-sectional area $\left(\mathrm{m}^{2}\right)$ of the incubation chamber and $t$ is the experiment duration (days).

APA and MBA were calculated using the following formulae:

$$
\begin{aligned}
& R_{\mathrm{APA}}=C \times V /(M \times T) \\
& R_{\mathrm{MBA}}=C_{\mathrm{f}} \times V /(M \times T)
\end{aligned}
$$

where $R_{\mathrm{APA}}$ represents sediment alkaline phosphatase activity ( $\mu \mathrm{g} \mathrm{g}^{-1} \mathrm{~h}^{-1}$ ), $R_{\mathrm{MBA}}$ represents sediment microbial activity $\left(\mu \mathrm{g} \mathrm{g}^{-1} \mathrm{~min}^{-1}\right), C$ represents nitrophenol concentration $\left(\mathrm{g} \mathrm{ml}^{-1}\right), C_{\mathrm{f}}$ (fluorescein con- centration) represents MBA activity $\left(\mathrm{g} \mathrm{ml}^{-1}\right), V$ is the volume of the reaction system (ml), $M$ is the reaction mass of the sediment samples ( $g$, as benchmark calculated by dry weight) and $T$ is the incubation time (min).

All data were analysed using SPSS v.18.0 software. Data were compared with 1-way ANOVA, followed by Tukey's multiple range tests for post hoc comparisons at a significance level of 0.05. Prior to statistical analyses, raw data were first processed in Microsoft Excel 2003, and the percentage data (including TOC, TON, TP content) were arcsine-transformed before comparison analysis. Normal distribution of the data and homogeneity of variances among treatments were verified before the ANOVA was carried out. The figures were created with OriginPro v.8.0 software.

\section{RESULTS}

\subsection{Visual observations and water quality in the mesocosm}

When razor clams were added to the chambers, they began to plunge into the sediment quickly and destroyed the initial sediment surface, leaving tubular channels. During the experiment, the clams seldom occurred on the sediment surface, but their siphons occasionally extended above the sediment surface. The siphon holes were sometimes covered by sediment, making them invisible. At the end of the experiment, the sediment surface of the control group remained smooth and had a thin oxidation zone that was approximately $0.85 \mathrm{~cm}$ deep, as revealed by the brown colour of the sediment. The clams extended the brown-black oxidation zone to a depth of approximately $5-8 \mathrm{~cm}$, which suggests that bioturbation stimulated the formation of the oxidized zone due to dissolved oxygen from the overlying water being brought into the sediments by the clams.

The temperature and salinity in the mesocosm ranged from 23.4 to $29.0^{\circ} \mathrm{C}$ and from 23.1 to $26.9 \mathrm{ppt}$, respectively. Both increased with the experiment time. The $\mathrm{pH}$ was $8.60 \pm 0.13$, and the DO was greater than $4.90 \mathrm{mg} \mathrm{l}^{-1}$. The $\mathrm{NH}_{4}{ }^{+}-\mathrm{N},\left(\mathrm{NO}_{3}{ }^{-}+\mathrm{NO}_{2}{ }^{-}\right)$$\mathrm{N}$ and $\mathrm{PO}_{4}{ }^{3-}-\mathrm{P}$ were $1.05 \pm 0.25,18.68 \pm 6.72$ and $0.58 \pm 0.11 \mathrm{mg} \mathrm{l}^{-1}$, respectively.

\subsection{Sediment characteristics}

TON and TOC contents in the sediment ranged from 0.358 to $0.416 \%$ dry weight (DW) and 1.028 to 
$1.204 \%$ DW, respectively, throughout the $30 \mathrm{~d}$ experiment. ANOVA results showed that TON and TOC in the surface sediment $(0-2 \mathrm{~cm}$ layer $)$ were significantly affected by clam density (ANOVA, $F_{3,8}=$ $10.554, \mathrm{p}=0.004[\mathrm{TON}] ; F_{3,8}=4.863, \mathrm{p}=0.033$ [TOC]). However, there were no clear differences in sediment in the $2-5$ or $5-8 \mathrm{~cm}$ layers among the treatment groups $(p=0.086$ and 0.068 for TON at $2-5$ and $5-8 \mathrm{~cm}$, respectively; $\mathrm{p}=0.591$ and 0.710 for TOC at $2-5$ and $5-8 \mathrm{~cm}$, respectively). The mean values of TOC and TON in the 3 treatments with clams (low, medium and high densities) were significantly lower than those in the control groups on the sediment surface $(0-2 \mathrm{~cm}$ layer) (Tukey's HSD, $\mathrm{p}<0.05$; Table 1). The values of TP in the surface and bottom sediments were more variable with significant differences among groups, and these values decreased significantly with increasing clam density (ANOVA, $F=5.77, \mathrm{p}=0.021$; Table 1). The final MBA and APA contents of the sediment were about 3-4 times those values before the trial, and these contents in the surface and bottom sediments were significantly higher in the high-density treatment than those in the lowdensity treatment and control group (ANOVA, $F_{3,8}=$ $112.198, \mathrm{p}<0.001[0-2 \mathrm{~cm}], F_{3,8}=5.617, \mathrm{p}=0.023$ $[5-8 \mathrm{~cm}]$ for MBA; ANOVA, $F_{3,8}=14.508, \mathrm{p}=0.01$ $[0-2 \mathrm{~cm}], F_{3,8}=4.570, \mathrm{p}=0.038[5-8 \mathrm{~cm}]$ for $\mathrm{APA}_{i}$ Tukey's HSD, p < 0.05); however, the values in the middle sediments $(2-5 \mathrm{~cm})$ of all groups did not change significantly (ANOVA, $F_{3,8}=0.750, \mathrm{p}=0.552$ for MBA; ANOVA, $F_{3,8}=3.529, \mathrm{p}=0.068$ for APA).

\subsection{SOC}

SOC rates ranged from 41.43 to $79.23 \mathrm{mmol} \mathrm{m}^{-2}$ $\mathrm{d}^{-1}$. There were significant differences in the SOC among treatments on all sampling days (2-way ANOVA, $\left.F_{3,40}=100.99, \mathrm{p}<0.001\right)$. Oxygen fluxes across the sediment-water interface increased with increasing density from the beginning to Day 24 . However, at the end of the experiment (on Day 30), the SOC in the medium-density treatment was significantly lower than that in the control and other treatments (Fig. 2).

\subsection{Nutrient fluxes}

During the experiment, ammonium showed a release flux in all chambers, with the exception of the low-density group on Day 6 (Fig. 3A). The efflux of ammonium increased significantly with increases in density and from Day 6 to Day 24 (2-way ANOVA, $F_{3,40}=23.672, \mathrm{p}<0.001$ for density; $F_{4,40}=37.430, \mathrm{p}<$ 0.001 for time; Fig. 3A). The fluxes changed significantly with time; e.g. the nutrient fluxes of $\left(\mathrm{NO}_{3}{ }^{-}+\right.$ $\mathrm{NO}_{2}{ }^{-}$)-N and $\mathrm{PO}_{4}{ }^{3-}-\mathrm{P}$ in the control groups changed significantly and most of them showed an increasing trend with time. There was a decreasing trend in the fluxes of all nutrients after Day 18 in the high-density group; the $\mathrm{NH}_{4}{ }^{+}-\mathrm{N}$ fluxes of all treatments increased with time before Day12. On Day 6, the nitrate + nitrite was absorbed by the sediments of each cham-

Table 1. Total organic nitrogen (TON), total organic carbon (TOC), total phosphorus (TP), microbial activity (MBA) and alkaline phosphatase (APA) in the sediments of different treatments (razor clam density levels) at different sediment depths. Data are means $\pm \mathrm{SD}(\mathrm{n}=3)$. Different superscript letters indicate differences between treatments at the same depth (Tukey's HSD, $\mathrm{p}<0.05)$; no letters indicate no significant difference between treatments at the same depth

\begin{tabular}{|lcccccc|}
\hline $\begin{array}{l}\text { Sediment } \\
\text { layer }(\mathrm{cm})\end{array}$ & Treatment & TON $(\%)$ & TOC $(\%)$ & TP $(\%)$ & $\begin{array}{c}\text { MBA } \\
\left(\mu \mathrm{g} \mathrm{g}^{-1} \mathrm{~min}^{-1}\right)\end{array}$ & $\begin{array}{c}\text { APA } \\
\left(\mu \mathrm{g} \mathrm{g}^{-1} \mathrm{~h}^{-1}\right)\end{array}$ \\
\hline \multicolumn{2}{l}{ Beginning of experiment } \\
$\begin{array}{l}\text { Fresh sediment } \\
\text { End of experiment }\end{array}$ & $0.358 \pm 0.005$ & $1.151 \pm 0.016$ & $0.128 \pm 0.001$ & $4.946 \pm 0.211$ & $23.242 \pm 2.039$ \\
$0-2$ & & & & & \\
& Control & $0.409 \pm 0.004^{\mathrm{b}}$ & $1.204 \pm 0.017^{\mathrm{b}}$ & $0.112 \pm 0.002^{\mathrm{b}}$ & $13.372 \pm 0.690^{\mathrm{a}}$ & $103.993 \pm 7.703^{\mathrm{a}}$ \\
& Low & $0.380 \pm 0.011^{\mathrm{ab}}$ & $1.150 \pm 0.047^{\mathrm{ab}}$ & $0.108 \pm 0.009^{\mathrm{ab}}$ & $17.318 \pm 0.755^{\mathrm{b}}$ & $94.900 \pm 4.191^{\mathrm{a}}$ \\
& Medium & $0.358 \pm 0.009^{\mathrm{a}}$ & $1.081 \pm 0.056^{\mathrm{a}}$ & $0.086 \pm 0.023^{\mathrm{ab}}$ & $17.504 \pm 0.381^{\mathrm{b}}$ & $94.762 \pm 4.142^{\mathrm{a}}$ \\
& High & $0.382 \pm 0.048^{\mathrm{a}}$ & $1.097 \pm 0.046^{\mathrm{ab}}$ & $0.071 \pm 0.014^{\mathrm{a}}$ & $23.815 \pm 0.896^{\mathrm{c}}$ & $117.468 \pm 0.830^{\mathrm{b}}$ \\
& Control & $0.383 \pm 0.009$ & $1.049 \pm 0.028$ & $0.113 \pm 0.032$ & $10.973 \pm 4.906$ & $78.881 \pm 4.807$ \\
& Low & $0.376 \pm 0.005$ & $1.096 \pm 0.025$ & $0.090 \pm 0.009$ & $12.248 \pm 3.736$ & $65.875 \pm 8.630$ \\
& Medium & $0.416 \pm 0.032$ & $1.060 \pm 0.053$ & $0.093 \pm 0.010$ & $11.547 \pm 0.493$ & $81.819 \pm 9.519$ \\
& High & $0.423 \pm 0.031$ & $1.118 \pm 0.112$ & $0.094 \pm 0.034$ & $15.530 \pm 5.306$ & $84.893 \pm 7.043$ \\
& Control & $0.367 \pm 0.009$ & $1.079 \pm 0.040$ & $0.132 \pm 0.031^{\mathrm{b}}$ & $9.076 \pm 2.783^{\mathrm{a}}$ & $64.901 \pm 2.821^{\mathrm{a}}$ \\
& Low & $0.370 \pm 0.009$ & $1.100 \pm 0.022$ & $0.097 \pm 0.005^{\mathrm{ab}}$ & $11.992 \pm 1.943^{\mathrm{a}}$ & $75.132 \pm 5.454^{\mathrm{ab}}$ \\
& Medium & $0.415 \pm 0.016$ & $1.028 \pm 0.024$ & $0.096 \pm 0.004^{\mathrm{ab}}$ & $10.844 \pm 0.403^{\mathrm{a}}$ & $76.855 \pm 2.479^{\mathrm{ab}}$ \\
& High & $0.395 \pm 0.036$ & $0.996 \pm 0.057$ & $0.085 \pm 0.014^{\mathrm{a}}$ & $17.615 \pm 4.170^{\mathrm{b}}$ & $79.316 \pm 7.848^{\mathrm{b}}$ \\
\hline
\end{tabular}




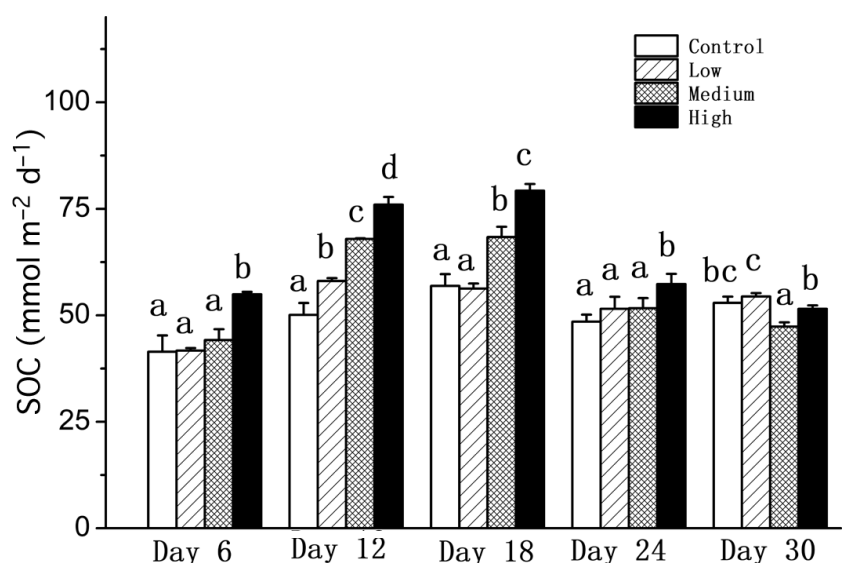

Fig. 2. Sediment oxygen consumption (SOC) rates determined in the razor clam experimental chambers. Data are means $+\mathrm{SD}(\mathrm{n}=3)$. Different letters indicate significant differences between treatments on the same experimental days (Tukey's HSD, $\mathrm{p}<0.05$ )

ber; the nitrite + nitrate fluxes of the different density treatments began to release from the sediment to the overlying water beginning on Day 12, whereas this occurred in the control group after Day 24 (Fig. 3B). The efflux rate of nitrite + nitrate increased significantly with the increase in clam density in the chambers and showed higher effluxes in the 3 density treatments than those in the control from Day 12 to Day 24 (2-way ANOVA, $F_{3,40}=182.353, \mathrm{p}<0.001$ [density]; Tukey's HSD, p < 0.05; Fig. 3B). Phosphate levels of the control group showed uptake at all incubation times, and the influx rates presented a declining trend with experimental time. However, the phosphate fluxes of all 3 density treatments were released from the sediments on all days except Day 6 (Fig. 3C). The effluxes from the treatment chambers were higher than those in the control (2-way ANOVA, $F_{3,40}=108.054, \mathrm{p}<0.001$ [density]; Tukey's HSD, $\mathrm{p}<0.05$; Fig. 3C). The efflux rates in the treatment chambers were higher than those in the control chambers from Day 6 to Day 24 (Tukey's HSD, p < 0.05). The efflux rates of the medium-density treatment were significantly higher than those of the other treatments on Day 30 (Tukey's HSD, p < 0.05).

\section{DISCUSSION}

In the present study, the effects of Sinonovacula constricta on sediment properties (TOC, TP, TON, APA, MBA) and nutrient fluxes $\left(\mathrm{NH}_{4}{ }^{+}, \mathrm{NO}_{3}{ }^{-}+\mathrm{NO}_{2}{ }^{-}\right.$, $\mathrm{PO}_{4}{ }^{3-}$ ) varied significantly among different treatments during the experiment, indicating that $S$. constricta
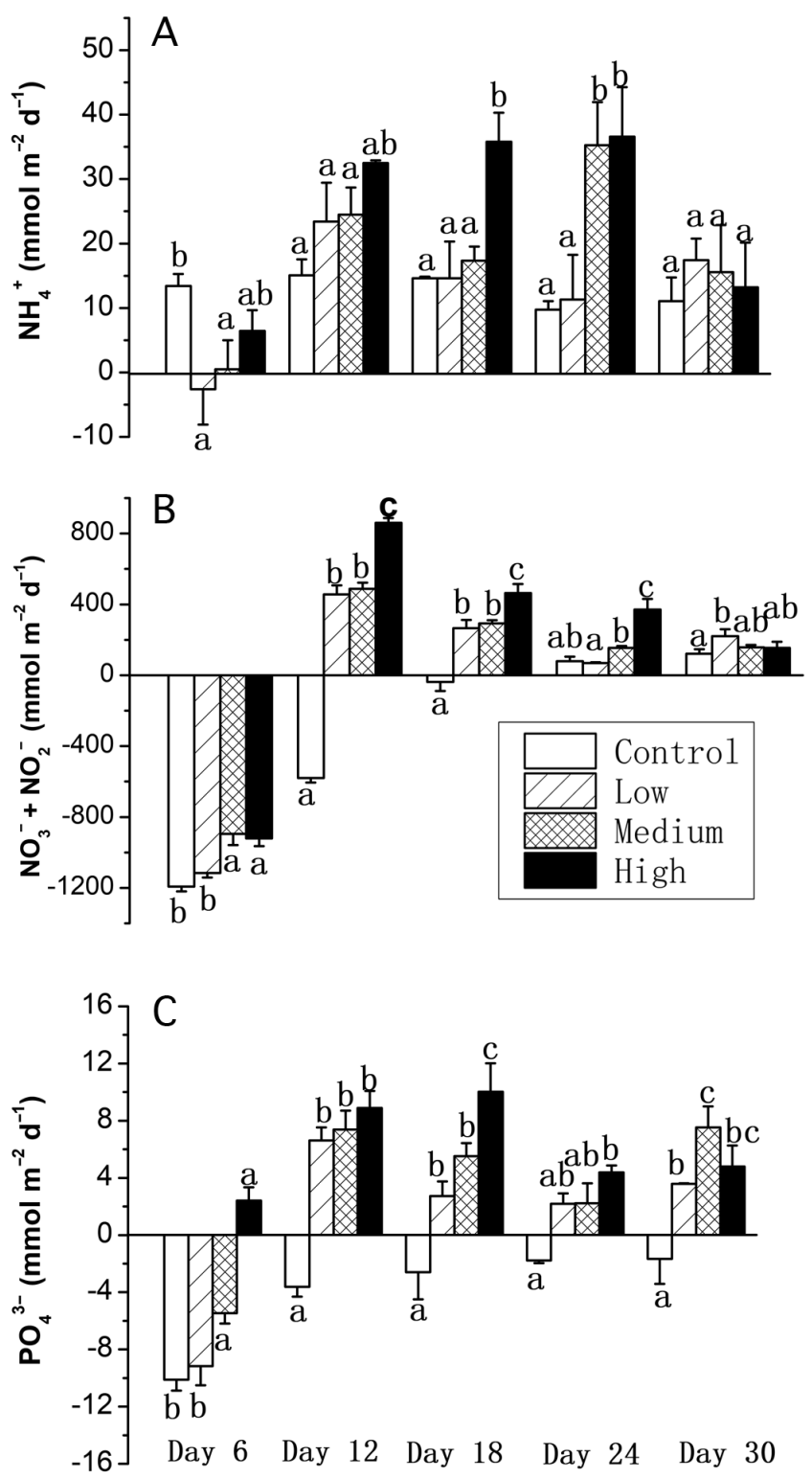

Fig. 3. Nutrient fluxes across the sediment-water interface for control, low-density, medium-density and high-density razor clam treatments. (A) Ammonium; (B) nitrate + nitrite; (C) phosphate. Data are means +/- SD $(n=3)$. Letters indicate differences between treatments on the same experimental days; means not sharing a common letter are significantly different (Tukey's HSD, $\mathrm{p}<0.05$ )

not only plays a key role in remediation of effluents by consuming algae but also evidently impacts nutrient recycling and enhances the mineralization process in aquaculture wastewater treatment ecosystems. The levels of TOC, TON and TOP in the surface sediments of the treatment groups were significantly lower than those in the control (Table 1), which may be because bioturbation promotes the entry of fresh organic particles from the surface of 
the sediment along the burrow into the sediment, and microbial-mediated mineralization accelerates the decomposition of organic matter, suggesting that bioturbation by the clams promotes the reduction of organic substances in the sediment. MBA and APA are indices of microorganism activity and, theoretically, positively related to the number of microbes and organic matter (Jiao et al. 2011). However, in our study the increased MBA and APA seems conflictive to the decreased TOC, TON and TOP on the surface in clam groups compared with that in the control (Table 1). This result is likely due to the pseudofeces and feces produced by the clams on the surface of the sediment, which contain a higher number of microbes with less organic matter (Cognie \& Barille 1999, Novais et al. 2016) and are very diffuse (Baker et al. 1998).

SOC is the most widely used indicator for measuring the total mineralization of benthic organisms. The SOC value is usually proportional to the organic matter content in the sediment and can be approximately equal to the total mineralization of direct or indirect biochemical oxidation of organic matter (Thamdrup \& Dalsgaard 2000). As a filterfeeding shellfish, S. constricta ingests and assimilates organic particulate matter from the overlying water and reduces the accumulation of organic matter on the sediment surface. On the other hand, the metabolic waste of the clam and its own mucus increase the enrichment of the sediment to a certain degree. In present study, the upward trend of SOC fluxes with increasing density and culture time at the beginning of the experiment and the downward trend later (after Day 18; Fig. 2) is probably due to the fact that the microbes proliferated rapidly and decomposed large amounts of organic matter in the sediment during the early stage of the experiment (Ye et al. 2018). The mineralization of sediment organic matter and the sedimentation of organic matter are a dynamic equilibrium process, and Day 18 may have been the turning point. Nicholaus \& Zheng (2014) also found that the SOC flux in their experimental group was significantly greater than that in the control. However, the sedimentation rate of the treatment group in the late stage of this experiment showed a downward trend, which may be due to an increase in feeding and bio-assimilation of the clams, leading to the decrease in organic matter in the sediment. These results further indicate that the long-term bioturbation activities of $S$. constricta would reduce the accumulation of organic matter in the sediment of the aquaculture wastewater treatment systems.
Nitrification is the microbial-mediated process of converting ammonia $\left(\mathrm{NH}_{4}^{+}\right)$into nitrate, in which the nitrate is turned into molecular nitrogen $\left(\mathrm{N}_{2}\right)$ or nitrous oxide $\left(\mathrm{N}_{2} \mathrm{O}\right)$ through denitrification, or into $\mathrm{NH}_{4}{ }^{+}$again by ammonization (Zhong et al. 2015). The results obtained in the present study showed that the release of $\mathrm{NH}_{4}{ }^{+}-\mathrm{N}$ and $\left(\mathrm{NO}_{3}{ }^{-}+\mathrm{NO}_{2}{ }^{-}\right)-\mathrm{N}$ increased with incubation time, which implies that clam bioturbation may break the dynamic balance of nitrification and denitrification and speed up $\mathrm{N}$ cycling across the sediment-water interface. Several reports have suggested that increased animal excretion and the accumulation of $\mathrm{NH}_{4}{ }^{+}-\mathrm{N}$ in the anoxic sediment may enhance the release of $\mathrm{NH}_{4}{ }^{+}-\mathrm{N}$ from the sediment into the overlying water (Svensson 1997, Zhang et al. 2011). The shellfish introduce fresh organic matter into the burrow linings and promote oxygen and nitrate influxes from the overlying water into the anoxic sediment (Zhong et al. 2015), which may stimulate the mineralization of organic matter. In this study, the $\mathrm{NH}_{4}{ }^{+}$fluxes were significantly improved in the treatment with $S$. constricta, and the TON contents of different density treatments on the surface sediment $(0-2 \mathrm{~cm})$ were significantly lower than those in the control group at the end of the experiment. These findings indicate that the bioturbation of $S$. constricta enhanced the release of $\mathrm{NH}_{4}{ }^{+}-$ $\mathrm{N}$ and $\mathrm{N}$ element mineralization, especially on the sediment surface. The flux measurements in this study indicate that $S$. constricta favoured an influx of $\left(\mathrm{NO}_{3}{ }^{-}+\mathrm{NO}_{2}{ }^{-}\right)-\mathrm{N}$ from the overlying water into the sediment at the initial stage, which may be because the nitrification rate in the burrows of $S$. constricta did not support a net flux of nitrate out of the sediment. Denitrification at the initial stages consumed more nitrate than was produced during ventilation. Bertics \& Ziebis (2009) found that burrowing activity may enhance the surface area available for microbial colonization and chemical reactions, resulting in the diffusion of nutrients from the sediment. The increase in the nitrate concentration in the bottom water and the sediment-water interface stimulates the release of $\mathrm{NO}_{3}{ }^{-}+\mathrm{NO}_{2}{ }^{-}$fluxes from the sediment. From Day 12, the study showed the release of nitrate and nitrite from the sediments in all treatments, and the $\mathrm{NO}_{3}{ }^{-}+\mathrm{NO}_{2}{ }^{-}$fluxes at different $S$. constricta densities were higher than those in the control group. Increasing trends of nutrient fluxes in the control and decreasing trends in the clam groups with time (Fig. 3) suggests that organic matter accumulated during the experiment and could be remediated by the bioturbation of the clams. These results indicate that the influence of the high level of burrowing of 
S. constricta stimulates additional oxygen uptake by the sediment and accelerates the nitrification process in the sediments. For the eutrophication of water bodies, nitrification and denitrification are indispensable processes for eliminating $\mathrm{N}$ pollution in sediments (Sun et al. 2010). Our previous research found that bioturbation of $S$. constricta increased the abundances of the bacterial phyla Betaproteobacteria, Actinobacteria and Nitrospirae in the sediment, which oxidize nitrite to nitrate (Lukwambe et al. 2018). Thus, enhanced release of $\mathrm{N}$ nutrients in the present study has important implications for the positive effects of $S$. constricta bioturbation on accelerating nitrification and bioremediation of wastewater treatment systems.

Similarly, the oxygen and redox potentials supplied during ventilation of benthic animals in burrows might influence the mineralization of organic phosphate matter in sediments (Waldbusser et al. 2004). The influx of oxygen during irrigation of benthic animals may have mobilized the organic phosphate of sediments and released the dissolved inorganic phosphate into the overlying water. Bates \& Neafus (1980) also found that bioturbation increased the rate of phosphate release from the sediment by 2 times under the same conditions (such as DO and $\mathrm{pH}$ ). In our study, the results showed the release of phosphate in different density treatments and the uptake of phosphate in the control groups (Fig. 3C), and the TP contents in the surface $(0-2 \mathrm{~cm})$ and bottom $(5-8 \mathrm{~cm})$ sediments of different density treatments (Table 1) were significantly lower than those in the control group at the end of the experiment, suggesting bioturbation of the clams accelerated the release of P. In addition, the burrowing activity of $S$. constricta makes the diffusive flux of phosphate break the oxide layer of the surface sediment. The results of the present study show an increase in the release of nitrogen and phosphate from the sediment into the overlying water (Fig. 3). These nutrients can be a rich source of food for microalgae in wastewater treatment ecosystems. S. constricta feed on microalgae and reduce the concentrations of inorganic nutrients in the overlying water. This cycle can reduce the excessive amounts of organic matter in pond effluents and convert them into $S$. constricta biomass. Ultimately, the purpose of purifying the intensive aquaculture wastewater pond was fulfilled.

As the clams need food to eat and may produce waste themselves, they should be applied with other components in bioremediation systems. The reasonable combination and area ratio of different components (or sections) are expected in the ecological treatment system of aquaculture wastewater. Lukwambe et al. (2018) conducted an experiment on a commercial scale with high treatment efficiency, which included 4 sequential areas: the physical settlement ( $1 / 5$ of the total area), biofilms and aeration (1/5 of the total area), the clam area (2/5 of the total area), and the wetlands (1/5 of the total area). However, further investigations are needed to develop better or more optimized models of the treatment system.

\section{CONCLUSIONS}

This study showed that the clam $S$. constricta can change the physical and chemical properties of aquaculture wastewater ecosystem sediment. Bioturbation accelerates the benthic release of $\mathrm{N}$ and $\mathrm{P}$ nutrient fluxes and the mineralization of organic matter particles in the sediment, slowing the accumulation of organic matter on the sediment surface in aquaculture wastewater ecosystems. At the same time, benthic bioturbation increased the aerobic rates and microbial activities in the sediment. The increased reproduction of microorganisms is beneficial to various biochemical reactions and enhances the self-purification ability in aquaculture wastewater treatment systems. Therefore, bioturbations of $S$. constricta have ecological benefits for the remediation of aquaculture wastewater.

Acknowledgements. This study was supported by the Zhejiang Public Welfare Technology Research Program of China (ZPWTP) (LGN18C190008) and the K.C. Wong Magna Fund in Ningbo University.

\section{LITERATURE CITED}

Bagdanavičiūtè I, Umgiesser G, Vaičiūtè D, Bresciani M, Kozlov I, Zaiko A (2018) GIS-based multi-criteria site selection for zebra mussel cultivation: addressing end-ofpipe remediation of a eutrophic coastal lagoon ecosystem. Sci Total Environ 634:990-1003

Baker SM, Levinton JS, Kurdziel JP, Shumway SE (1998) Selective feeding and biodeposition by zebra mussels and their relation to changes in phytoplankton composition and seston load. J Shellfish Res 17:1207-1213

Bates MH, Neafus NJE (1980) Phosphorus release from sediments from Lake Carl Blackwell, Oklahoma. Water Res 14:1477-1481

Battin T (1997) Assessment of fluorescein diacetate hydrolysis as a measure of total esterase activity in natural stream sediment biofilms. Sci Total Environ 198:51-60

Bertics VJ, Ziebis W (2009) Biodiversity of benthic microbial communities in bioturbated coastal sediments is controlled by geochemical microniches. ISME J 3:1269-1285 
Breda S, Chiesa S, Freitas R, Figueira E and others (2018) Biogeochemical dynamics and bioaccumulation processes in Manila clam: implications for biodiversity and ecosystem services in the Ria de Aveiro Lagoon. Estuar Coast Shelf Sci 209:136-148

Bu XF, Qu KM, Ma SS, Sun WJ (2003) Treatment technology of wastewater in marine culture and its application prospect. Mar Fish Res 24:85-90

* Cai SZ, Li DP, Tang XY, Li HR and others (2017) Distribution of external phosphorus in the sedimentary phosphorus forms under different disturbances. Huan Jing Ke Xue 38:4607-4614

Cognie B, Barille L (1999) Does bivalve mucus favour the growth of their main food source, microalgae? Oceanol Acta 22:441-450

* Creed RP, Taylor A, Pflaum JR (2010) Bioturbation by a dominant detritivore in a headwater stream: litter excavation and effects on community structure. Oikos 119:1870-1876

Dollar SJ, Smith SV, Vink SM, Obrebski S, Hollibaugh JT (1991) Annual cycle of benthic nutrient fluxes in Tomales Bay, California, and contribution of the benthos to total ecosystem metabolism. Mar Ecol Prog Ser 79:115-125

Du WJ (2016) Upper thermal, salt tolerance traits and early growth comparative study of Sinonovacula constricta selection group and family. MSc thesis, Shanghai Ocean University (in Chinese with English Abstract)

Granéli E, Carlsson P, Legrand C (1999) The role of C, N and $\mathrm{P}$ in dissolved and particulate organic matter as a nutrient source for phytoplankton growth, including toxic species. Aquat Ecol 33:17-27

Gupta VK, Ali I (2013) Environmental water: advances in treatment, remediation and recycling. Elsevier, Amsterdam, p 30-35

Hopkins JS, Hamilton RD II, Sandifer PA, Browdy CL (1993) The production of bivalve mollusks in intensive shrimp ponds and their effect on shrimp production and water quality. World Aquac 24:74-77

Jiao XG, Gao CS, Sui YY, Zhang XY, Ding GW (2011) Research on soil microbial ecology under different soil organic matter levels in farmland. Zhongguo Nong Ye Ke Xue 44:3759-3767 (in Chinese with English Abstract)

Jones AB, Dennison WC, Preston NP (2001) Integrated treatment of shrimp effluent by sedimentation, oyster filtration and macroalgal absorption: a laboratory scale study. Aquaculture 193:155-178

Klerks PL, Kascak A, Cazan AM, Adhikary ND and others (2018) Effects of the razor clam Tagelus plebeius on the fate of petroleum hydrocarbons: a mesocosm experiment. Arch Environ Contam Toxicol 75:306-315

Lukwambe B, Yang W, Zheng YQ, Nicholaus R and others (2018) Bioturbation by the razor clam (Sinonovacula constricta) on the microbial community and enzymatic activities in the sediment of an ecological aquaculture wastewater treatment system. Sci Total Environ 643:1098-1107

MacDonald JA, Rittman BE (1993) Performance standards for in situ bioremediation. Environ Sci Technol 27: 1974-1979

Marinho-Soriano E, Nunes SO, Carneiro MAA (2009) Nutrients' removal from aquaculture wastewater using the macroalgae Gracilaria birdiae. Biomass Bioenergy 33: 327-331

Meysman FJ, Middelburg JJ, Heip CH (2006) Bioturbation: a fresh look at Darwin's last idea. Trends Ecol Evol 21: 688-695

Michaud E, Desrosiers G, Mermillod-Blondin G, Sundby B,
Stora G (2006) The functional group approach to bioturbation: II. The effects of the Macoma balthica community on fluxes of nutrients and dissolved organic carbon across the sediment-water interface. J Exp Mar Biol Ecol 337:178-189

Murphy J, Riley JPA (1962) Modified single solution method for the determination of phosphate in natural waters. Anal Chim Acta 27:31-36

Nicholaus R, Zheng ZM (2014) The effects of bioturbation by the Venus clam Cyclina sinensis on the fluxes of nutrients across the sediment-water interface in aquaculture ponds. Aquacult Int 22:913-924

Novais A, Souza AT, Ilarri M, Pascoal C, Sousa R (2016) Effects of the invasive clam Corbicula fluminea (Müller, 1774) on an estuarine microbial community. Sci Total Environ 566-567:1168-1175

Qin W, Lu K, Zheng Z, Yang W, Zheng Y (2017) Purification effect on the treatment efficiency of Asparagus schoberioides Kunth and Sinonovacula constricta Lamarck in monoculture or polyculture on the intensive marine shrimp culture tail-water. J Ningbo University 30:35-41 (in Chinese with English Abstract)

Sayler GS, Puziss M, Silver M (1979) Alkaline phosphatase assay for freshwater sediments: application to perturbed sediment systems. Appl Environ Microbiol 38:922-927

Sun SZ, Zheng ZM, Lu KH, Zhu JY and others (2010) Effects of Bellamya aeruginosa bioturbation on nutrient fluxes across sediment-water interface of algal bloom water body. Shengtaixue Zazhi 29:730-734 (in Chinese with English Abstract)

Svensson JM (1997) Influence of Chironomus plumosus larvae on ammonium flux and denitrification (measured by the acetylene blockage- and the isotope pairingtechnique) in eutrophic lake sediment. Hydrobiologia 346:157-168

Thamdrup B, Dalsgaard T (2000) The fate of ammonium in anoxic manganese oxide-rich marine sediment. Geochim Cosmochim Acta 64:4157-4164

Thayer CW (1979) Biological bulldozers and the evolution of marine benthic communities. Science 203:458-461

Kian XL, Li DS, Dong SL, Liu G, Qi Z, Lu J (2001) Water quality of closed polyculture of penaeid shrimp with tilapia and constricted tagelus. Ying Yong Sheng Tai Xue Bao 12:287-292 (in Chinese with English Abstract)

Tian SY, Zhang T, Song CZ, Gao YN (2016) Influence of bioturbation on the environmental behavior of sedimentassociated organic pollutants in marine ecosystem. J Tianjin Univ Sci Technol 31:1-7 (in Chinese with English Abstract)

Waldbusser G, Marinelli R, Whitlach RB, Visscher PT (2004) The effects of infaunal biodiversity on biogeochemistry of coastal marine sediments. Limnol Oceanogr 49: 1482-1492

Wang RC, Wang ZP (2008) Science of marine shellfish culture. China Ocean University Press, p 302-307 (in Chinese with English Abstract)

Wrede A, Dannheim J, Gutow L, Brey T (2017) Who really matters: influence of German Bight key bioturbators on biogeochemical cycling and sediment turnover. J Exp Mar Biol Ecol 488:92-101

Wu ZK, Qiu XC, Zhang XF, Liu ZW, Tang YL (2018) Effects of Anodonta woodiana on water quality improvement in restoration of eutrophic shallow lakes. Hupo Kexue 30: 1610-1615 (in Chinese with English Abstract)

Ye BB, Li GD, Jin M, Chu ZS (2018) Effects of Margarya 
melanioides bioturbatian on sediment of Ottelia acuminate constructed wetlands. Huanjing Gongcheng Jishu Xuebao 8:257-263 (in Chinese with English Abstract)

Zhang ZD, Wang F, Dong SL, Gao QF, Zhang MZ, Song Q, Zhang JD (2011) A preliminary study on structural optimization in polycultural systems of Ctenopharyngodon idellus with Hypophthalmichthys molitrix and Litopenaeus vannamei. Period Ocean Univ China 41:60-66 (in Chinese with English Abstract)

Zheng YQ, Zheng ZM, Qin WJ (2017) Effects of bioturbation by the razor clam, Sinonovacula constricta, on vertical

Editorial responsibility: Marianne Holmer,

Odense, Denmark distribution of phosphorus form in sediment in an aquaculture treatment ecosystem. Oceanol Limnol Sin 48: 161-170 (in Chinese with English Abstract)

* Zhong D, Wang F, Dong SL, Li L (2015) Impact of Litopenaeus vannamei bioturbation on nitrogen dynamics and benthic fluxes at the sediment-water interface in pond aquaculture. Aquacult Int 23:967-980

Ziemann DA, Walsh WA, Saphore EG, Fulton-Bennet K (1992) A survey of water quality characteristics of effluent from Hawaiian aquaculture facilities. J World Aquacult Soc 23:180-191

Submitted: July 25, 2018; Accepted: December 17, 2018 Proofs received from author(s): February 21, 2019 